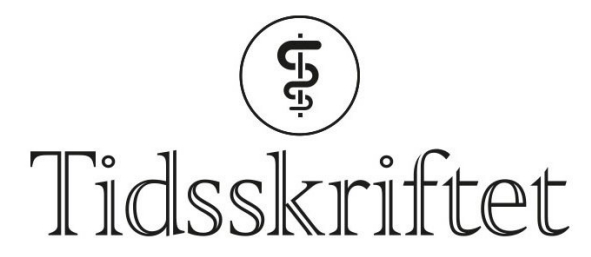

DEN NORSKE LEGEFORENING

\title{
Sjuskeri satt i system
}

TIDLIGERE I TIDSSKRIFTET

\section{JULIE DIDRIKSEN}

E-post: julie.didriksen@tidsskriftet.no Tidsskriftet

Det sto et lite innlegg om legeattester og høflighet på trykk i Tidsskriftet nr. 1/1918. Innskriveren hadde sett seg lei av det sjuskete formatet legeattester ofte opptrer i. Ågi ut uet halvt avrevet ark med frynset kant» rett fra notisblokken sømmet seg slett ikke, særlig når disse attestene ofte skulle gis videre til andre instanser sammen med andre dokumenter. Og var det ikke egentlig veldig sjelden at man så en sjuskete presteattest? Hvorfor skulle legene være noe dårligere? Under følger redaksjonell omtale av innlegget fra samme nummer, der erfaringene ble behørig bekreftet (Tidsskr Nor Lægeforen 1918; 38: 46-7).

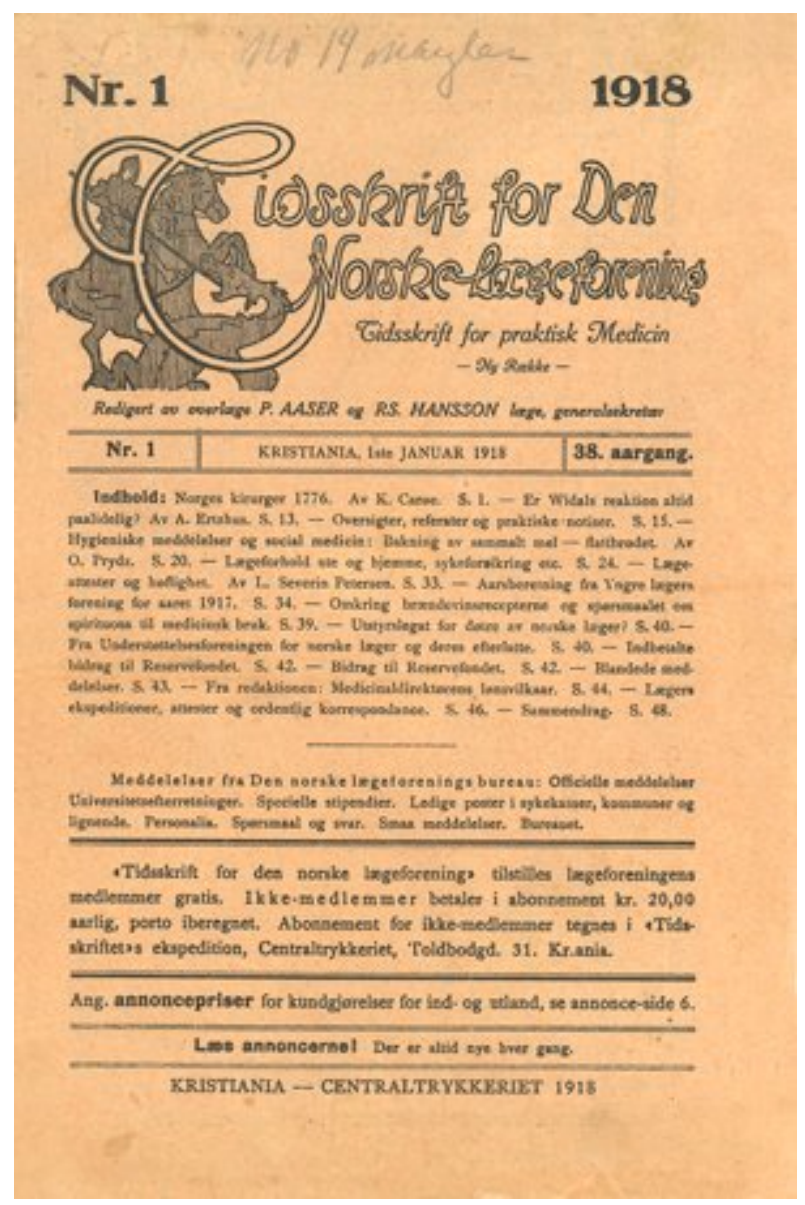


Lægers ekspeditioner, attester og ordentlig korrespondance.

Overlæge Severen Petersens artikel foran om «lægeattester og høflighet» gir os høve til at gjenta en opfordring, som vi for mange aar siden i dette tidsskriftet rettet til vore kolleger. Det er desværre ikke nyt av aaret det sjuskeri, som norske læger viser i sin korrespondance, ved avgivelse av attester $\mathrm{m}$. v. Men det synes, som om sjuskeriet endog er i stigende.

I stillings medfør har vi rikelig anledning til at bekræfte kollega Petersens erfaringer. Især siden notisblokhefterne - som NB. er beregnet paa bruk ved referater, fo r e $1 \emptyset$ b i g e notater o. lign. - er blit almindelige, er sjuskeriet rent sat i system, hadde vi nær sagt. Selv om man «bare» korresponderer med en kollega, burde almindelig høflighet tilsi brevskriveren at bruke papir av skikkelig format, ikke de receptblanketter m. m., som hr. Petersen nævner. Dertil kommer, at er man slurvet i sin mere private korrespondance, er man det som regel ogsaa, naar man staar overfor offentlige myndigheter. Og der k a n det trække konsekvenser efter sig.

Vi kan eksempelvis nævne, at der i lægeforeningens arkiv findes som selvstændige «skrivelser»: visitkort (endog om 3 saker), brevkort (om vigtige spørsmaal), blokblader i mindste format q. s. superque, avrevne oktav, hvis rande endog vedk. ikke har giddet rette med en saks, - og lign. «ekspeditioner» fra vore kolleger. Hvis det nu bare gjaldt en bagatel, rettelse av en adresse, anmodning om et skema og lign. kurante ting, kunde en mindre formel skrivelse endda til nød undskyldes. Skjønt enkel -ikke simpel - høflighet dog burde tilsi vedk. ialfald at iagtta orden i sine eksepditioner. Men det blir verre, naar det indløper skrivelser, som kræver mere eller mindre undersøkelser og svar, - som ofte maa videreforsendes til erklæring fra andet hold, - som blir utgangspunkt for en hel, indviklet «sak» om sykekassetakster, lægers ansættelsesvilkaar, bostedsforhold m. m. Værst er det naturligvis, naar det gjælder a t t e s t e r eller lign., som skal eller kan tjene som offentlige dokumenter. Det maa, som av hr. P. nævnt, erindres, at a l l e skrivelser, som indløper til et kontor, maa paaføreres journalnummer og perforeres til senere indheftning. Hvorledes kan slikt ske med en bloknoteslap, en receptblanket, et visitkort eller lign.? Aarevis efter kan der komme - og kommer slet ikke sjelden - op spørsmaal, som kræver, at det gamle dokument maa hentes frem fra arkivet. Kan man vente, at en bloknoteslap, receptblanket etc. skal kunne opbevares i arkiver med tusener av skrivelser?

Angaar det en mere vigtig sak, burde der aldrig brukes mindre end stort kvartark, - gjerne bare ett blad ( $\left.1 \frac{1}{2} \mathrm{ark}\right)$, hvis der ikke skal ske paategning paa selve skrivelsen. Gjælder det mindre vigtige ting, saa bruk a l d r i g mindre end almindelig postpapir (oktavark), og er det en ren kurant ekspedition (forandring av adresse, manglende nr. av «Tidsskr. » o. lign.), kan ogsaa et brevkort være fuldt tilstrækkelig. Et almindelig halvark (av en blok) med paatrykt navn og adresse er praktisk til mindre viktige ekspeditioner.

Ved skrivelser til det of f e $\mathrm{n} \mathrm{t} \mathrm{l}$ i g e maa a $\mathrm{l} \mathrm{t}$ i d brukes godt papir og enten folio (store lange ark) eller saakaldt stort kvartark. Og altid tydelig skrift, - underskrift ikke mindst, saa ikke bare skriftkloke kan tyde hieroglyferne.

Men under enhver omstændighet - enten det gjælder mere private eller offentlige saker maa ekspeditionen være o r d e n $\mathrm{t}$ l i g, ikke slurvet, med blækklatter og sjusket utydelig skrift etc. Det tilsiger høflighet og god tone. Spar heller de flotte konvolutter, som enkelte ekscellerer i, og bruk skikkelig papir. Konvolutter gaar saa allikevel i papirkurven. Det bør helst ikke et brev gjøre. Vi kjender et tilfælde, hvor en sjusket skreven ansøkning om et legat, som vedk. læge ellers hadde gode utsigter til at faa, var aarsak til, at han blev forbigaat. Man skal altid iagtta decorum, sa de gamle. Og det gjælder endnu.

De norske læger er for tiden som regel ikke kjendt for at være ordentlige i sin korrespondance. La det bli anderledes herefter. Formen er ogsaa et tegn paa kultur. Heller litt for meget end for litet av form. Red. 
Publisert: 18. september 2017. Tidsskr Nor Legeforen. DOI: 10.4045/tidsskr.17.0708 (C) Tidsskrift for Den norske legeforening 2020. Lastet ned fra tidsskriftet.no 